\title{
Errata in \\ Middle-range theory: Without it what could anyone do? by Nancy Cartwright
}

(Errata en

\begin{abstract}
Middle-range theory: Without it what could anyone do?
\end{abstract} de Nancy Cartwright)

In the article Middle-range theory: Without it what could anyone do?, by Nancy Cartwright, published in THEORIA, vol. 35/3, pp. 269-323, the section Lullius Acknowlegments mistakenly repeats the text of the Acknowledgements section of the paper. The correct text for the Lullius Acknowlegments section is the following:

This work collects the contents of lectures given by Prof. Nancy Cartwright as Raimundus Lullius Lectures during the Xth Conference of the Spanish Society of Logic, Methodology, and Philosophy of Science, that took place in UNED, Madrid (13-16 November 2028).

En la sección Lullius Acknowlegments del artículo Middle-range theory: Without it what could anyone do?, de Nancy Cartwright, publicado en THEORIA, vol. 35/3, pp. 269323, se repitieron por error los agradecimientos incluidos en la sección Acknowledgments. El texto que debería figurar como Lullius Acknowlegments es el siguiente:

This work collects the contents of lectures given by Prof. Nancy Cartwright as Raimundus Lullius Lectures during the Xth Conference of the Spanish Society of Logic, Methodology, and Philosophy of Science, that took place in UNED, Madrid (13-16 November 2028). 